\title{
Koroner Anjiyografi Uygulanacak Hastaların Yaşam Kalitesi ve Kaygı Düzeyleri
}

\author{
(D) Pınar Yel, 1 @ Serap Ünsar 2 \\ ${ }^{1}$ Ege Üniversitesi Hemşirelik Fakültesi, İç Hastalıkları Hemşireliği Anabilim Dalı, İzmir \\ ${ }^{2}$ Trakya Üniversitesi Sağlık Bilimleri Fakültesi, Hemşirelik Bölümü, İç Hastalıkları Hemşireliği Anabilim Dalı, Edirne
}

\begin{abstract}
Özet
Amaç: Bu kesitsel çalışma; koroner anjiyografi işlemi uygulanacak hastaların yaşam kalitesi ile kaygı seviyeleri arasındaki ilişkiyi saptamak ve bunları etkileyen bireysel ve hastalık ile ilgili özellikleri belirlemek amacıyla yapıldı.

Yöntemler: Çalışmaya Ekim 2007-Şubat 2008 tarihleri arasında Edirne ilinde bir üniversite hastanesinin kardiyoloji kliniğine başvuran 202 hasta alındı. Veriler, hasta tanıtım formu, SF-36 Yaşam Kalitesi Ölçeği ve Spielberger Durumluk-Sürekli Kaygı Envanteri ile toplandı. Verilerin analizinde yüzdelik, ortalama, Student-t testi, Mann Whitney-U testi, KruskalWallis $\mathrm{H}$ testi tekniği kullanıldı.

Bulgular: Çalışmaya katılanların \%58.9'u erkek, \%85.6'sı evli, \%37.6'si 55 yaşın altında, \%52.5'i ilkokul mezunudur. Bu çalışmada kadınların yaşam kalitesi erkeklere göre daha düşük, kaygı düzeyleri ise daha yüksek bulunmuştur. Yaş, medeni durumu, gelir ve eğitim düzeyi gibi kişisel özellikler; klinik tanı, ilaç kullanma durumu vb. hastalıkla ilişkili özellikler yaşam kalitesi ve kaygı düzeyini etkilemektedir. Hastaların kaygı puanı arttıkça yaşam kalitesi azalmaktadır $(p<0.05)$.

Sonuç: Hemşireler, koroner arter hastalığı olup girişimsel işlem yapılacak hastaların yaşam kalitesini iyileştirmek ve kaygı düzeylerini azaltmak için kişisel (yaş, eğitim durumu gibi) ve hastalığa ilişkin (klinik tanı, ilaç kullanma gibi) özelliklerini göz önüne alarak bakım ve eğitim vermelidirler.
\end{abstract}

Anahtar sözcükler: Kaygı (Anksiyete); koroner anjiyografi; Yaşam kalitesi.

\section{Quality of Life and Anxiety Levels of Patients with Coronary Angiography}

\section{Abstract}

Objective: This cross sectional study was planned to investigate the relationship between quality of life and level of anxiety in the patients coronary angiography and to determine the personal and disease factors that affects this relationship.

Methods: This study were included 202 patients who applied to University Faculty Cardiology Clinic between October 2007 and February 2008 in Edirne. Data were collected by Patient Information Form, Short Form Health Survey-36 (SF-36) and Spielberger Stait-Trait Anxiety Inventory. The data were analysed by percentage, average, student- t test, Mann Whitney $U$ test, the technique of Kruskall-Wallis $\mathrm{H}$ test.

Results: The $\% 58.9$ of the patients were male, $\% 85.6$ of them were married, $\% 37.6$ of them were under 55 years of age, $\% 52$ of them were primary school graduates. According to the findings of the study, women have less quality of life than man and anxiety levels were higher. The personal properties as age, marital status, level of education and amount of income, profession, and the conditions related to the disease as the clinical diagnosis, conditio the usage of drug affect quality of life and 
anxiety. The patient's quality of life decreases as the state trait anxiety scores increase $(p<0.05)$.

Conclusion: Nurses should give care and education considering the characteristics of the individual (age, educational status, etc.) and disease (clinical diagnosis, drug use, etc.) in order to improve the quality of life and reduce anxiety levels of patients with coronary artery disease who will undergo invasive procedures.

Keywords: Anxiety; coronary angiography; quality of life.

Cite this article as: Yel P, Ünsar S. Quality of Life and Anxiety Levels of Patients with Coronary Angiography. Turk J Cardiovasc Nurs 2020;11(24):7-15.

G ünümüzün gelişmiş toplumlarında koroner arter hastalığı (KAH) mortalite ve morbiditenin en önde gelen sebeplerinden biridir ve Amerika Birleşik Devletleri $(A B D)$ 'nde yetişkin nüfustaki yıllık ölümlerin \%42'sini oluşturmaktadır. Ülkemizde yapılan "Türk Erişkinlerinde Kalp Sağlığı ve Risk Faktörleri (TEKHARF)" çalışmasının verilerine göre 37 yaş ve üzerindeki bireylerin 2006 yılında genel mortalite oranı, 27 milyon vakada binde 12.3 olarak dikkate alınınca, ülkemizde bir yıl içerisinde 340 bin yetişkin yaşamını yitirmekle birlikte $400-420$ bin yeni vakaya da koroner arter hastalığı tanısı konulmaktadır. ${ }^{[1,2]}$

Dünya Sağlık Örgütü (DSÖ)'nün 2015 yılındaki verilerinde, yaklaşık 56 milyon ölümün, 40 milyonunu bulaşıcı olmayan hastalıklar ve bunların \%45'ini de (17.7 milyon) kardiyovasküler olaylara bağlı ölümler oluşturmaktadır. Türkiye'de kalp hastalıklarına bağlı ölüm oranı, tüm ölümlerin \%40. 4'ünü oluşturur. ${ }^{[3]}$ Koroner anjiyografi, birey ve toplum sağlığında önemli bir yeri olan koroner arter hastalığının tanısını koymada halen klinik olarak altın standarttır. ${ }^{[4]}$

Koroner anjiyografi, invaziv bir tanı yöntemi ve hayati değeri yüksek olan kalp gibi bir organın tanılanmasında kullanılan, yapılacak uygulama ile ilgili bilinmezliklerin olması sebebiyle kişide ölüm korkusu ve bundan dolayı anksiyeteye neden olan bir işlemdir. ${ }^{[5]}$ Anksiyete nedeni tam olarak bilinmeyen ve bireyde iç çatışmaya dayanan herhangi bir tehdite yönelik gösterilen tepkidir. ${ }^{[6]} \mathrm{Bu}$ tepki, hastalıklara tanı koyarken veya tedavi uygulamalarında bulunurken bireyin psikolojik durumunu ön plana çıkarmaktadır.

Kronik hastalıklar bireyin yaşam kalitesini de çok boyutlu olarak negatif yönde etkiler. ${ }^{[7]}$ Yaşam kalitesi bireyin yaşadığı çevre ile değer yargıları içerisinde, beklentileri, yaşam standartları, amaçları ve ilgilerini de ele alarak kişinin yaşamdaki pozisyonunu algılaması olarak tanımlanır. Genel anlamıyla 'iyi olma durumu' diye tanımlanan, bireyin psikolojik durumu, fiziksel sağlığı, inançları ve sosyal çevresiyle olan ilişkilerinden hoşnut ve mutlu olmayı içeren geniş bir kavramdır. ${ }^{[8]}$

Woldecherkos ve ark.'nın (2007) çalışmasında koroner anjiyografi uygulaması için bekleyen hastaların yaşam kalitesinin ve psikolojik durumunun olumsuz yönde etkilendiği belirtilmiştir. ${ }^{[9]}$ Mott ve ark. (1999) yapmış olduğu çalışmada kardiyak kateterizasyon öncesi verilen psikolojik desteğin anksiyete düzeylerinin azalttığı belirtilmiştir. ${ }^{[10]}$ Demir ve Aslantaş'ın (2014) çalışmasında perkutan koroner anjiyoplasti ve koroner anjiyografi işlemi yapılmadan önce müzik ile birlikte uygulanan gevşeme egzersizleri ile bireylerin kaygı düzeylerinin azaldığı belirtilmiştir. ${ }^{[11]}$ Dural ve Sarıtaş'ın ${ }^{[12]}$ (2017) çalışmasında akut koroner sendrom tanısı alan hastaların yaşam kalitesinin olumlu ya da olumsuz birçok faktörden etkilendiği ve orta düzeyde olduğu belirtilmiştir.

Hemşireler, bireylerin yaşam kalitesini ve işlem öncesinde yaşadıkları anksiyeteyi belirlemeli ve bu durumu olumlu yönde geliştirebilecek gerekli hemşirelik uygulamalarını planlamalıdır. Çalışmamız, koroner anjiyografi işlemi planlanan bireylerin yaşam kalitesi ve kaygı düzeylerini etkileyen bireysel ve hastalığa ait özellikleri belirlemek ve aralarındaki ilişkiyi saptamak amacıyla planlanmıştır.

\section{Gereç ve Yöntemler}

\section{Araştırmanın Şekli}

Koroner anjiyografi işlemi uygulanacak hastaların yaşam kalitesi ile kaygı düzeylerini etkileyen faktörleri belirlemek amacıyla planlanmış tanımlayıcı kesitsel bir çalışmadır. Araştırmanın evrenini; Ekim 2007-Şubat 2008 tarihlerinde Edirne ilinde bir üniversite hastanesinin kardiyoloji kliniğine başvurup koroner anjiyografi uygulaması planlanan hastalar oluşturmaktadır. Çalışmanın örneklemine söz konusu kliniğe başvurup, koroner anjiyografi uygulaması planlanan toplam 442 hastadan, çalışmaya katılmayı kabul eden, iletişim sorunu olmayan ve 32-78 yaş aralığında toplam 202 birey alındı. Çalışmadaki veriler birey tanıtım formu, SF-36 Yaşam Kalitesi Ölçeği (Short Form Health Survey-36) ve Spielberger Durumluk-Sürekli Kaygı Envanteri (Stait-Trait Anxiety Inventory/STAI) ile elde edildi.

Veri Toplama Araçları: Çalışmanın verileri; hastaların kişisel ve hastalık ile ilgili özellikleri tanıtan bilgi formu, SF-36 Yaşam Kalitesi Ölçeği ve Spielberger Durumluk-Sürekli Kaygı Envanteri kullanılarak elde edildi.

Hasta Tanıtım Formu: Hasta tanıtım formu, konu ile ilgili literatür taranarak araştırmacılar tarafından hazırlanıp, kişisel ve hastalıkla ilgili sorulardan oluşmaktadır. Kişiye ait özel- 
likler ilk bölümde; yaş, cinsiyet, beden kitle indeksi, eğitim durumu, meslek, birlikte yaşadığı kişiler, medeni durumu, aylık gelir düzeyi, yaşantısının büyük çoğunluğunun geçtiği yer, çocuk sayısı ve sosyal güvenlik durumunu kapsayan 11 sorudan oluşmaktadır. Hastalığa ait sorular ise ikinci bölümde; sigara-alkol alışkanlıkları, beslenme alışkanlıkları, kronik hastalık varlığı, daha önce hastanede yatma durumu ve yatma sıklığı, kullanılan ilaçlar ve günlük alınan ilaç sayısı, klinik tanı, kalp ameliyatı geçirme öyküsünün varlığı, birinci derece yakınlarında kalp hastalığı hikayesi, düzenli egzersiz yapma durumu ve yapılan egzersizin türünü kapsayan 13 soruyu içermektedir.

SF- 36 Yaşam Kalitesi Ölçeği: Ölçek; 1987 yılında Ware tarafından, klinik uygulama ve araştırmalarda her yaştan bireye uygulanabilen, genel popülasyon incelemelerinde ve sağlık politikalarının değerlendirilmesinde kullanılmak üzere hazırlanmış, çok boyutlu ölçüm sağlayan jenerik ölçüt özelliğinde olan kişisel değerlendirme aracıdır. En önemli üstünlüğü fiziksel yeterlilik ile ilişkili fonksiyonları ölçmesi, kısıtlılığı ise cinsel işlevlerin değerlendirilmesi için soru içermemesidir. SF-36 ölçeği 1992 yılında geliştirilmiş, 1999 yılında ise Koçyiğit ve arkadaşları tarafından geçerlik ve güvenilirlik çalışması yapılmıştır. ${ }^{[13]}$ Ölçek, sağlığı çok yönlü ele alarak sekiz boyutta 36 madde ile incelemektedir. Bunun yanında 'şuandaki sağlığınızı bir yıl öncesi ile karşılaştırdığınızda nasıl buluyorsunuz?' sorusu ile son bir yılda sağlık algısındaki değişimi içeren bir madde daha yer almaktadır. Ancak bu madde ölçek değerlendirilirken göz önünde bulundurulmaz. Diğer maddelerdeki tüm ifadeler son bir ay içerisindeki verileri değerlendirir. Bu ölçek sayesinde yaşam kalitesinin alt boyutları ve toplam yaşam kalitesi ölçülebilir. Yaşam kalitesinin ve alt boyutlarının toplam puanı 0 ila 100 arasında değiş̧erek, 0 sağlık durumunun kötü 100 ise iyi olduğunu belirtmektedir.

Spielberger Durumluk-Sürekli Kaygı Envanteri: Spielberger ve arkadaşlarının geliştirdiği 'hiç ve tamamiyle' arasında değişenleri içeren likert tipinde bir araçtır. ${ }^{[14]}$ Ölçeğin, N. Öner tarafından 1977 yıında geçerlilik ve güvenirliği yapılmıştır. ${ }^{[15]}$ Sürekli ile durumluk kaygıyı ayrı değerlendiren ve 20 'şer adet soru içeren iki bölümden oluşmaktadır. Belirli bir zaman ve koşulda kişinin hissettiklerini durumluk kaygı anketi ile, içinde bulunulan durum ve koşuldan bağımsız kişinin genellikle nasıl hissettiğini ise sürekli kaygı anketi ile belirlenir. Puan seviyesi 36- 41 arasında değişmekte ve 0 ila 30 puan aralığı düşük, 31 ila 49 puan aralığı orta, 50 ve üstünde alınan puan ise anksiyete seviyesinin yüksek olduğunu göstermektedir.

\section{Araştırmanın Etik Yönü}

Araştırmaya başlamadan önce Trakya Üniversitesi Tıp Fakültesi Etik Kurulu ve kurumdan izin alındı. Çalışmada insan olgusunun kullanımı kişisel hakların korunmasını gerektirdiğinden çalışma boyunca İnsan Hakları Helsinki Deklerasyonu'na sadık kalındı (Etik Kurul No: 2007/150).

\section{Bulgular}

Çalışma grubundaki hastaların \%37.6'sının 55 yaşın altında, \%58.9'unun erkek, \%52.5'inin ilkokul mezunu, \%85.6'sının evli, \%35.1'inin ev hanımı, \%41.6'sının klinik tanısının angina pektoris, \%45.5'inin günde alınan ilaç sayısının 1-5 arasında olduğu belirlendi (Tablo 1).

\begin{tabular}{|c|c|c|}
\hline Bireysel Özellikler & $\mathbf{n}$ & $\%$ \\
\hline \multicolumn{3}{|l|}{ Cinsiyet } \\
\hline Kadın & 83 & 41.1 \\
\hline Erkek & 119 & 58.9 \\
\hline \multicolumn{3}{|l|}{ Yaş } \\
\hline$<55$ & 76 & 37.6 \\
\hline $55-65$ & 65 & 32.2 \\
\hline$>65$ & 61 & 30.2 \\
\hline \multicolumn{3}{|l|}{ Medeni hali } \\
\hline Dul & 27 & 13.4 \\
\hline Evli & 173 & 85.6 \\
\hline \multicolumn{3}{|l|}{ Eğitim düzeyi } \\
\hline Okuma-yazması olmayan & 35 & 17.3 \\
\hline Okur/yazar & 23 & 11.4 \\
\hline İlkokul mezunu & 106 & 52.5 \\
\hline Ortaokul mezunu & 13 & 6.4 \\
\hline Lise mezunu & 16 & 7.9 \\
\hline Üniversite mezunu & 9 & 4.5 \\
\hline \multicolumn{3}{|l|}{ Meslek } \\
\hline İşçi & 12 & 5.9 \\
\hline Memur & 9 & 4.5 \\
\hline Emekli & 57 & 28.2 \\
\hline Serbest meslek & 30 & 14.9 \\
\hline Çiftçi & 23 & 11.4 \\
\hline Ev hanımı & 71 & 35.1 \\
\hline \multicolumn{3}{|l|}{ Hastalığa ilişkin özellikler } \\
\hline \multicolumn{3}{|l|}{ Klinik Tanı } \\
\hline Miyokard infarktüsü (MI) & 60 & 29.7 \\
\hline Angina pektoris & 84 & 41.6 \\
\hline $\begin{array}{l}\text { Diğer (Kalp yetersizliği, dilate } \\
\text { kardiyomiyopati, akut } \\
\text { akciğer ödemi) }\end{array}$ & 58 & 28.7 \\
\hline \multicolumn{3}{|l|}{ Günlük alınan ilaç sayısı } \\
\hline Hiç ilaç kullanmıyor & 59 & 29.2 \\
\hline 5'en az & 92 & 45.5 \\
\hline $5-10$ & 46 & 22.8 \\
\hline 10'dan fazla & 5 & 2.5 \\
\hline
\end{tabular}

MI: Miyokard İnfarktüsü. 
Araştırmaya katılan hastalar, yaşam kalitesi ölçeğinin alt boyutu olan fiziksel fonksiyondan $65.7 \pm 20.5$, sosyal fonksiyondan $67.9 \pm 16.2$, fiziksel rol kısıtlıklarından $45.9 \pm 48.5$, sağlı-

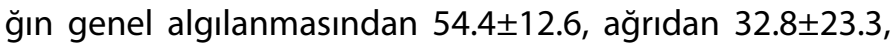
emosyonel rol kısıtlıklarından $45.4 \pm 49.1$, mental sağlıktan $46.4 \pm 15.1$, enerjiden $39.1 \pm 16.8$, puan aldı. Hastaların durumluk kaygi puan ortalamaları $42.5 \pm 6.3$, sürekli kaygı puan ortalaması $46.3 \pm 6.0$ olarak bulundu (Tablo 2 ).

Yaşam kalitesi ölçeği ile kaygi envanterinin puan ortalamalarının cinsiyete göre dağılımında; erkeklerin sağlığın genel algılanması, sosyal fonksiyon, enerji, fiziksel fonksiyon puan ortalaması kadınlara göre yüksek $(p=0.002,0.001,0.001$, 0.001 , sırasıyla) sürekli kaygı puan ortalaması ise düşük bulundu ( $p=0.001$ ) (Tablo 3 ).

Yaşam kalitesi ölçeği ve kaygi envanterinin puan ortalamalarının yaşa göre dağılımında; 65 yaşın üzerinde olan hastaların 65 yaşın altında olan gruba göre emosyonel rol kısıtlıkları puanı yüksek saptandı ( $p=0.022)$, kaygı seviyeleri arasında anlamlı bir fark bulunmadı (Tablo 3).

Yaşam kalitesi ölçeği ile kaygi envanterinin puan ortalamalarının medeni haline göre dağılımında; evli olanların dullara göre enerji, sağlığın genel algılanması ve fiziksel fonksiyon alt grup puanları yüksek ( $p=0.025,0.044,0.031)$, sürekli kaygı puanı ise düşük olduğu belirlendi $(p=0.001)$ (Tablo 3 ). Yaşam kalitesi ölçeği ile kaygi envanterinin puan ortalamalarının eğitim seviyesine göre dağılımında; eğitim düzeyi arttıkça yaşam kalitesinin arttığı, kaygı düzeyinin azaldığı belirlendi (Tablo 3).

Yaşam kalitesi ölçeği ile kaygi envanterinin puan ortalamasının klinik tanıya göre dağılımında; miyokart infarktüsü tanısıyla yatırılan hastaların mental sağlık, fiziksel fonksiyon,

\begin{tabular}{|c|c|c|}
\hline $\begin{array}{l}\text { SF-36 yaşam kalitesi ölçeği } \\
\text { kaygı puanı türü }\end{array}$ & Ort. \pm SS & Min.-Max. değer \\
\hline Fiziksel fonksiyon & $65.7 \pm 20.5$ & $0-100$ \\
\hline Sosyal fonksiyon & $67.9 \pm 16.2$ & $0-100$ \\
\hline Fiziksel rol kısıtlıkları & $45.9 \pm 48.5$ & $0-100$ \\
\hline Sağlığın genel algılaması & $54.4 \pm 12.6$ & $0-100$ \\
\hline Mental sağlık & $46.4 \pm 15.1$ & $0-100$ \\
\hline Enerji & $39.1 \pm 16.8$ & $0-100$ \\
\hline Emosyonel rol kısıtlıkları & $45.4 \pm 49.1$ & $0-100$ \\
\hline Ağrı & $32.8 \pm 23.3$ & $0-100$ \\
\hline Sürekli kaygı & $46.3 \pm 6.0$ & $20-80$ \\
\hline Durumluk kaygı & $42.5 \pm 6.3$ & $20-80$ \\
\hline
\end{tabular}

Ort. \pm SS: Ortalama \pm Standart Sapma. enerji ve fiziksel rol kısıtlıklari puanları diğer gruplara göre yüksek ( $p=0.021,0.003,0.001,0.001$ sırasıyla), sürekli kaygı puan ortalaması ise düşük saptanmıştır ( $p=0.015$ ) (Tablo 4).

Yaşam kalitesi ölçeği ile kaygi envanterinin beden kitle indeksi, gelir düzeyi, yaş ve ilaç sayısı arasındaki korelasyona bakıldığında; yaş artışına bağlı ağı ile fiziksel fonksiyonun azaldığı ve ilerleyen yaş nedeniyle emosyonel rol kısıtıklarının daha az yaşandığı saptandı. Artan gelir düzeyi ile ağrı, fiziksel fonksiyon, enerji ve fiziksel rol kısıtlıkları düzeyinin arttığı ve sürekli kaygı düzeyinin azaldığı saptandı. Kullanılan ilaç sayısı arttıkça mental sağlık, fiziksel fonksiyon, fiziksel rol kısıtıkları düzeyi azalırken, enerji ile kaygı puanlarının arttığı belirlendi (Tablo 5).

Yaşam kalitesi ölçeği puanları ile kaygi envanterinin puanları arasındaki korelasyonda; mental sağlık, fiziksel fonksiyon, enerji, emosyonel rol kısıtlıkları, sosyal fonksiyon, fiziksel rol kısıtlıkları ve sağlığın genel algılanması alt boyutları ile kaygı envanteri arasında negatif bir ilişki belirlendi. Hastaların yaşam kaliteleri azaldıkça kaygı düzeyleri artmakta veya yaşam kalitesi arttıkça kaygı düzeyleri azalmaktadır (Tablo 6).

\section{Tartışma}

Çalışmamızda yaşam kalitesi ölçeği alt grup puan ortalamalarından; sağlığın genel algılanması (54.4 \pm 12.6$)$, fiziksel fonksiyon $(65.7 \pm 20.5)$, sosyal fonksiyon $(67.9 \pm 16.2)$ puan ortalamaları yüksek, mental sağlık (46.4 \pm 15.1$)$, emosyonel $(45.4 \pm 49.1)$ ve fiziksel rol kısıtlıkları $(45.9 \pm 48.5)$ puan orta-

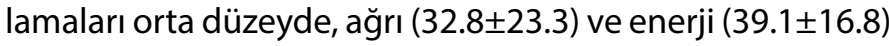
puan ortalaması ise düşük bulundu. Kaygı puan ortalamalarına bakıldığında sürekli kaygı puanı $(46.3 \pm 6.0)$ durumluk kaygi puanı (42.5 \pm 6.3 ) daha yüksek bulundu (Tablo 2).

Harkness ve ark.'nın ${ }^{[16]}$ (2003) çalışmasında kardiyak kateterizasyon işlemi için sıra bekleyen bireylerin yaşam kalitesi ile anksiyete seviyelerinin olumsuz etkilendiği belirlenmiştir. Arthur ve ark.'nın ${ }^{[17]}$ (2007) çalışmasında koroner anjiyografi işlemi uygulanacak hastalarda yaşam kalitesi düşük, anksiyete düzeyleri ise yüksek saptanmıştır. Wynne J ve ark.'nın ${ }^{[18]}$ (2004) çalışmasında ise koroner anjiyografi işlemi uygulanacak hastalarda sıra beklemenin, bireylerin yaşam kalitesini ve psikolojik durumunu negatif yönde etkilediği belirtilmiştir. Balcı ve Enç'in ${ }^{[19]}$ (2013) çalışmasında koroner anjiyografi işleminden önce görsel ve işitsel olarak verilen eğitimin, işlem sonrasında depresyon, anksiyete ve stres puan ortalamalarını düşürdüğü belirtilmiştir. Bizim çalışmamızda ise yaşam kalitesi ve kaygı düzeyinin önemli oranda etkilenmemesinin nedeni hastaların daha önce hastalıklarıyla ilgili tedavi almalarına bağlı olabileceği söylenebilir. 


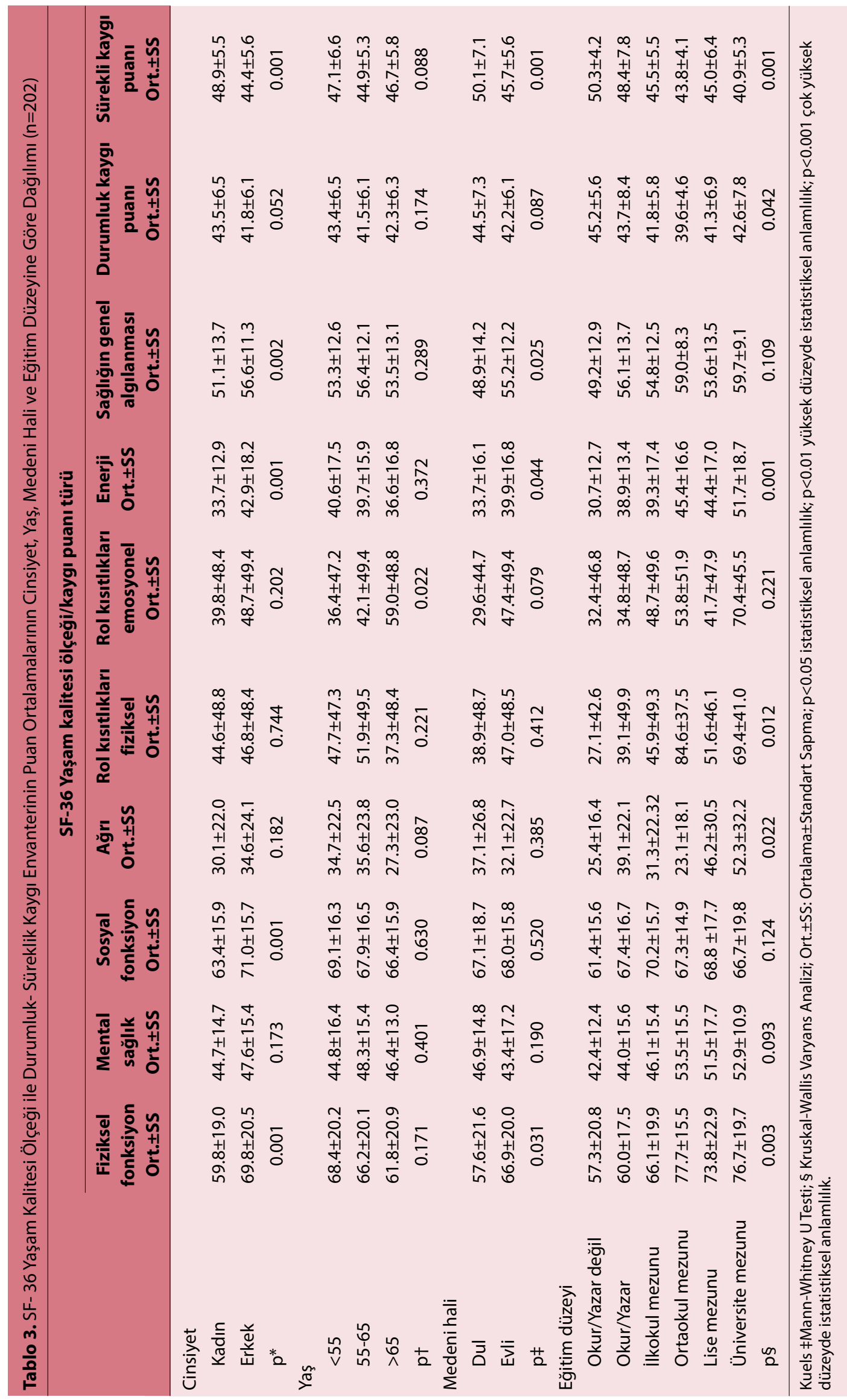




\begin{tabular}{|c|c|c|c|c|}
\hline $\begin{array}{l}\text { SF-36 yaşam kalitesi ölçeği } \\
\text { kaygı puanı türü }\end{array}$ & $\begin{array}{c}(n=60) \\
\text { Miyokard infarktüsü } \\
\text { Ort. } \pm S S\end{array}$ & $\begin{array}{l}\text { Klinik tanı } \\
\qquad(n=84) \\
\text { Angina pektoris } \\
\text { Ort. } \pm \text { SS }\end{array}$ & $\begin{array}{c}(n=58) \\
\text { Diğer (akut akc. ödemi vb) } \\
\text { Ort. } \pm S S\end{array}$ & pt \\
\hline Fiziksel fonksiyon & $73.3 \pm 21.0$ & $62.7 \pm 18.3$ & $62.1 \pm 21.0$ & 0.003 \\
\hline Sağlığın genel algılanması & $56.3 \pm 11.4$ & $54.7 \pm 11.4$ & $51.8 \pm 15.1$ & 0.149 \\
\hline Mental sağlık & $50.9 \pm 16.9$ & $43.9 \pm 14.5$ & $45.4 \pm 13.3$ & 0.021 \\
\hline Emosyonel rol kısıtlıkları & $55.0 \pm 50.2$ & $40.1 \pm 48.2$ & $40.9 \pm 48.6$ & 0.156 \\
\hline Enerji & $46.3 \pm 14.4$ & $36.3 \pm 15.3$ & $35.9 \pm 19.1$ & 0.001 \\
\hline Ağrı & $33.3 \pm 18.7$ & $29.5 \pm 25.9$ & $35.9 \pm 26.2$ & 0.326 \\
\hline
\end{tabular}

† Tek Yönlü Anova Ort. \pm SS: Ortalama \pm Standart Sapma; $p<0.05$ istatistiksel anlamlıık; $p<0.01$ yüksek düzeyde istatistiksel anlamlılık; $p<0.001$ çok yüksek düzeyde istatistiksel anlamlılık.

Araştırmamızda kadın hastaların erkeklere oranla yaşam kalitesinin düşük ve sürekli kaygı puan ortalamasının yüksek olduğu belirlendi (Tablo 3). Ünsar ve ark. (2007) ile Dilek ve ark.'nın (2010) yapmış oldukları çalışmada kadınların erkeklere göre yaşam kalitesinin daha düşük olduğu bulunmuştur. ${ }^{[20,21]}$ Woldecherkos ve ark.'nın (2007) çalışmasında erkeklerin anksiyete puanlarının kadınlara göre daha düşük olduğu belirtilmiştir. ${ }^{[9]}$ Çalışmamızda kadınların yaşam kalitelerinin düşük, kaygı düzeylerinin yüksek olmasının sebebi fiziksel rol ve sosyal fonksiyonlarda ki yetersizliğe bağlı olarak yaşam kalitesinin düştüğü ve bunun sonucunda kaygı düzeylerinin arttığı düşünülmektedir.

Araştırmamızda 65 yaşın üzerinde olan hastaların 65 yaşın altında olanlara göre iş hayatında ya da günlük aktiviteler- de emosyonel sorunlara bağlı olarak az sorun yaşadığı belirlendi. Yaş ile ağrı ve fiziksel fonksiyon puan ortalamaları arasında negatif yönde, emosyonel rol kısıtlıkları puanı ile arasında ise pozitif yönde korelasyon bulundu (Tablo 3, 5). Bireylerin yaş ile kaygı envanteri puanları ve korelasyonu incelendiğinde anlamlı bir fark bulunmadı. Göçgeldi ve $\operatorname{ark} . n ı n^{[22]}$ (2008) çalışmasında yaşın ilerlemesi ile yaşam kalitesinin düştüğü belirlenmiştir. Aydın ve ark.'nın ${ }^{[23]}$ (2002) çalışmasında ameliyat öncesi ve ameliyat sonrası değerlere bakıldığında emosyonel rol kısıtlılı̆ı sebebiyle bireylerin daha az sorun yaşadıkları belirtilmiştir. 65 yaşın üzerindeki bireylerin 65 yaşın altında olanlara göre iş hayatında ya da diğer günlük aktivitelerde emosyonel sorunlara bağlı az sorun yaşamasının nedeni çalışan kişilerin emek-

\begin{tabular}{|c|c|c|c|c|c|c|c|c|}
\hline \multirow[t]{2}{*}{$\begin{array}{l}\text { SF-36 yaşam kalitesi ölçeği } \\
\text { kaygı puanı türü }\end{array}$} & \multicolumn{2}{|c|}{$\begin{array}{c}(n=202) \\
\text { BKi }\end{array}$} & \multicolumn{2}{|c|}{$\begin{array}{l}\text { (n=191) } \\
{ }^{*} \text { Gelir }\end{array}$} & \multicolumn{2}{|c|}{$\begin{array}{c}(n=202) \\
\text { Yaş }\end{array}$} & \multicolumn{2}{|c|}{$\begin{array}{c}(n=143) \\
* * \text { ilaç sayısı }\end{array}$} \\
\hline & $\mathbf{r}$ & pt & $\mathbf{r}$ & pt & $\mathbf{r}$ & pt & $\mathbf{r}$ & pt \\
\hline Fiziksel fonksiyon & -0.03 & 0.658 & 0.18 & 0.009 & -0.15 & 0.034 & -0.35 & 0.001 \\
\hline Fiziksel rol kısıtlıkları & -0.04 & 0.953 & 0.22 & 0.003 & -0.10 & 0.149 & -0.16 & 0.022 \\
\hline Mental sağlık & 0.01 & 0.806 & 0.21 & 0.191 & 0.04 & 0.552 & -0.27 & 0.001 \\
\hline Ağrı & -0.03 & 0.965 & 0.16 & 0.025 & -0.15 & 0.031 & -0.03 & 0.643 \\
\hline Sosyal fonksiyon & -0.06 & 0.331 & -0.03 & 0.667 & -0.10 & 0.124 & -0.03 & 0.667 \\
\hline Emosyonel rol kısıtlıkları & 0.01 & 0.837 & 0.080 & 0.269 & -0.19 & 0.006 & 0.08 & 0.269 \\
\hline Enerji & 0.01 & 0.801 & 0.20 & 0.004 & -0.11 & 0.120 & 0.20 & 0.004 \\
\hline Sağlığın genel algılanması & 0.04 & 0.570 & 0.09 & 0.185 & -0.01 & 0.946 & 0.09 & 0.185 \\
\hline Sürekli kaygı puanı & 0.03 & 0.658 & -0.25 & 0.001 & -0.04 & 0.550 & 0.23 & 0.001 \\
\hline Durumluk kaygı puanı & -0.09 & 0.183 & -0.10 & 0.148 & 0.01 & 0.865 & 0.14 & 0.043 \\
\hline
\end{tabular}

† Pearson Korelasyon Analizi; BKI: Beden Kitle Indeksi; $p<0.05$ istatistiksel anlamlılık; $p<0.01$ yüksek düzeyde istatistiksel anlamlılık; $p<0.001$ çok yüksek düzeyde istatistiksel anlamlılık; ${ }^{* 11}$ kişinin geliri yok; ${ }^{*} 59$ kişi ilaç kullanmamakta. 
liye ayrıldıktan sonra iş hayatındaki stresi yaşamamalarına ve sosyal hayatta daha aktif rol alabilmelerine bağlı olacağı düşünülmektedir.

Araştırmamızda evlilerin dullara göre günlük aktivitelerini gerçekleştirirken daha az kısıtılık yaşadıkları, enerji düzeyleri ile sağlıklarının iyi olduğunu düşündükleri belirlenmiş ve sürekli kaygı puanı daha düşük saptanmıştır (Tablo 3). Göçgeldi ve ark.'nın ${ }^{[22]}$ (2008) çalışmasında dul olanların yaşam kalitesinin, evli ve bekar olanlarla karşılaştırıldığında düşük olduğu belirtilmiştir. Bahar ve ark. (2005) ile Astin ve ark. (2005) tarafından yapılan çalışmada medeni durumun anksiyete düzeylerini etkilemediği belirlenmiştir. ${ }^{[24,25]}$ Dul olan bireyler evli olanlar ile karşılaştıııldığında; yaşam kalitelerinin düşük, sürekli kaygı puan ortalamasının ise yüksek saptanmasının nedenini kadın cinsiyete ve sosyal desteğin (eş desteği vb.) yetersizliğinden kaynaklanabileceğini söyleyebiliriz.

Araştırmamızda eğitim düzeyi arttıkça yaşam kalitesinin arttığı ve kaygı puanının azaldığı belirlenmiştir (Tablo 3). Dilek ve ark.'nın ${ }^{[20]}$ (2010) çalışmasında koroner arter hastalığı olan kişilerin eğitim seviyelerindeki artışla yaşam kalitelerinin de artış gösterdiği belirtilmiştir. Özol ve ark. (2005)'nın yapmış oldukları çalışmada ise bireylerin eğitim düzeyi ile kaygı seviyeleri arasında istatiksel olarak anlamlı fark saptanmamıştır. $^{[26]}$ Kişinin eğitim seviyesi arttıkça, sağlık problemlerine sebep olacak durumlardan uzak durarak (kişisel bakım ve temizliğinde yetersizlik, kötü beslenme vb.), yaşam kalitesini arttıran yöntemleri (spor, sağlıklı beslenme vb.) etkin biçimde uygulayarak stresle baş etme yöntemlerini geliştirdiği ve olumlu davranışlarıyla daha sağlıklı bir yaşama kavuştuğu düşünülmektedir. Bireyin eğitim seviyesi arttıkça kaygı düzeyinin azalmasının nedeni, eğitim seviyesi yüksek kişilerin sosyoekonomik açıdan daha iyi yaşam şartlarında olmaları ve stres ile baş etme tekniklerini daha etkili bir şekilde kullanmalarından kaynaklandığı söylenebilir.

Araştırmamızda miyokard infarktüsü tanısı ile yatırılan has- taların diğer iki gruba göre yaşam kalitesi ve sürekli kaygı düzeyi daha düşük bulunmuştur (Tablo 4). Astin ve ark. (2005) tarafından yapılan çalışmada akut miyokard infarktüsü tanısı alan ve kalp ameliyatı olanlarda anksiyete ve depresyonun sağlığı negatif yönde etkilediği belirtilmiştir. [25] MI geçiren hastalar; daha önceden kısıtlılık yaşayacak herhangi bir semptom olmadan, ani başlayan göğüs ağrısıyla hastaneye başvurduklarından, önceden kalp yetmezliği tanısı alan, angina ve diğer kalp hastalıklarına sahip olan bireylere göre daha yüksek yaşam kalitesine ve daha düşük kaygı düzeylerine sahip oldukları söylenebilir.

Araştırmamızda yaşın ilerlemesi ile birlikte ağı ve fiziksel fonksiyonun azaldığı ve yaşın ilerlemesi ile ilişkili emosyonel rol kısıtlıklarının az yaşandığı saptanmıştır. Gelir düzeyinin artması ile ağrı, fiziksel fonksiyon, enerji ve fiziksel rol kısıtlıklarının da arttığı, kaygı düzeyinin ise azaldığı belirlenmiş̧ir. Kullanılan ilaç sayısı ve miktarı arttıkça mental sağlık, fiziksel fonksiyon, enerji düzeyi ve fiziksel rol kısıtlıkları azalmakta iken kaygı düzeyi artmaktadır (Tablo 5). Demir (2008)'in çaısşmasında bir günde kullanılan ilaç sayısı ve miktarındaki artışın yaşam kalitesini azalttığı belirtilmiştir. ${ }^{[27]}$

Çalışmamızda bireylerin kaygı düzeyleri arttıkça yaşam kalitesinin azaldığı veya yaşam kalitesi arttıkça kaygı düzeylerinin azaldığı görülmüştür (Tablo 6). Mott ve ark.(1999) tarafından yapılan çalışmada kardiyak kateterizasyon işleminden önce verilen psikolojik desteğin anksiyete düzeyini azalttığı, Wynne ve ark. (2004) ile Harkness ve ark. (2003)'nın yapmış oldukları çalışmada ise koroner anjiyografi ve kardiyak kateterizasyon için bekleyenlerin yaşam kalitesinin ve anksiyetenin negatif yönde etkilendiği belirtilmiştir. ${ }^{[10,18,16]}$

\section{Çalışmanın Sınırlııkları}

Bu araştırma Edirne ilinde yer alan bir Üniversite Hastanesinin Kardiyoloji Kliniğine başvuran hastalar ile sınırlı olduğu için bulunan sonuçlar topluma genellenemez.

\begin{tabular}{|c|c|c|c|c|}
\hline \multirow[t]{2}{*}{ SF-36 yaşam kalitesi ölçeği } & \multicolumn{2}{|c|}{ Sürekli kaygı puanı } & \multicolumn{2}{|c|}{ Durumluk kaygı puanı } \\
\hline & $\mathbf{r}$ & pt & $\mathbf{r}$ & pt \\
\hline Fiziksel fonksiyon & -0.43 & 0.001 & -0.21 & 0.003 \\
\hline Sosyal fonksiyon & -0.31 & 0.001 & -0.20 & 0.004 \\
\hline Rol kısıtlıkları fiziksel & -0.16 & 0.023 & -0.27 & 0.001 \\
\hline Emosyonel rol kısıtlıkları & -0.32 & 0.001 & -0.31 & 0.001 \\
\hline Mental sağlık & -0.36 & 0.001 & -0.52 & 0.001 \\
\hline Enerji & -0.48 & 0.001 & -0.30 & 0.001 \\
\hline
\end{tabular}

† Pearson Korelasyon Analizi; $p<0.05$ istatistiksel anlamlııı; $p<0.01$ yüksek düzeyde istatistiksel anlamlılık; $p<0.001$ çok yüksek düzeyde istatistiksel anlamlılık. 


\section{Sonuç ve Öneriler}

Çalışmamızda koroner anjiyografi işlemi uygulanacak hastaların işlem öncesinde bilgilendirilmesinden, tedavi ve bakım olanaklarından yararlanabilmesi için hastalardan yazılı onam alınmasından, koroner anjiyografinin koroner arter hastalığı tanısında sık kullanılan tanı yöntemi olmasından, koroner anjiyografi işlemi uygulanacak bireylerin kaygı seviyelerinin orta düzeyde olduğu ve yaşam kalitelerinden enerji ve ağrı alt boyutlarının en fazla etkilendiği genel sağlık algılaması, sosyal fonksiyon ve fiziksel fonksiyon alt boyutlarının ise en az etkilendiği belirlenmiştir.

Elde edilen verilere göre;

- Hemşirelerin koroner arter hastalığı tanısı alan ve koroner anjiyografi işlemi yapılması tasarlanan bireylere, hastaların yaşam kalitesini ve kaygı seviyelerini etkileyen bireysel (yaş cinsiyet, medeni durumu, gelir düzeyi ve eğitim durumu vb.) ve hastalığa ait özellikleri (klinik tanı, hastane deneyimi, sürekli kullanılan ilaç varlığı gibi) göz önünde bulundurarak bakım ve eğitim vermesi,

- Hemşirelerin işlem yapılması planlanan bireylerin yaşam kalitesini ve kaygı seviyelerini geçerliliği ve güvenilirliği yapılmış ölçekler ile değerlendirmesi ve uygun bakım protokollerini oluşturması,

- Hemşirelere, bireylerin yaşam kalitesi ile kaygı seviyelerini etkileyen bireysel (cinsiyet, yaş, eğitim ve gelir düzeyi vb) ve hastalıkla bağlantılı (klinik tanı, kullanılan ilaç sayısı vb) etkenler hakkında bilgi verilmesi

- Uygun hemşirelik bakımını planlamada bu bilgileri kullanmaları için desteklenmesi gerektiği önerilir.

- Ayrıca bu çalışmamızın fazla sayıda hasta içeren karşılaştırmalı çalışmalarla tekrarlanması önerilmektedir.

Etik Kurul Onayı: Araştırmanın yürütülebilmesi için Trakya Üniversitesi Tıp Fakültesi Etik Kurulu'ndan 13.09.2007 tarihinde 2007/150 protokol nolu etik kurul izni ve kurum izni alınmıştır.

Hakem Değerlendirmesi: Dış bağımsız.

Çıkar Çatışması: Yazarlar arasında herhangi bir çıkar çatışması bulunmamaktadır.

Yazarlık Katkıları: Konsept: S.Ü., P.Y.; Dizayn: S.Ü., P.Y.; Veri Toplama veya İşleme: P.Y.; Analiz veya Yorumlama: S.Ü., P.Y.; Literatür Arama: P.Y.; Yazan: P.Y., S.Ü.

\section{Kaynaklar}

1. Akdemir N, Canlı Özer Z. Kardiyovasküler Sistem Hastalıkları ve Hemşirelik Bakımı. In: Akdemir N, Birol L, editors. İç Hastalıkları ve Hemşirelik Bakımı. 4th ed. Ankara: Akademisyen Tıp Kitapevi; 2018.

2. Onat A, Karakoyun S, Akbaş T, Karadeniz FÖ, Karadeniz Y,
Çakır H, et al. Turkish Adult Risk Factor survey 2014: Overall mortality and coronary disease incidence in Turkey's geographic regions. [Article in Turkish] Turk Kardiyol Dern Ars 2015;43(4):326-332. [CrossRef]

3. Şencan I, Keskinkılıç B, Ekinci B, Öztemel A, Sarıoğlu G, Çobanoğlu N, et al. Türkiye Kalp ve Damar Hastalıkları Önleme ve Kontrol Programı Eylem Planı (2015-2020). Ankara:T.C. Türkiye Halk Sağlığı Kurumu; 2015. p. 1-63.

4. Ökçün B, Gürmen T, Koroner Anjiyografi Komplikasyonları ve Tedavisi. Turkiye Klinikleri Journal of Internal Medical Sciences 2007;3(42):48-72.

5. Gallagher R, Trotter R, Donoghue J. Preprocedural concerns and anxiety assessment in patients undergoing coronary angiography and percutaneous coronary interventions. Eur J Cardiovasc Nurs 2010;9(1):38-44. [CrossRef]

6. Ertekin Yazııı E, Yazıcı K. Kardiyovasküler Hastalıklarda Psikososyal Risk Etkenleri. Anadolu Psikiyatri Dergisi 2003;4:106112.

7. Braunwald E. Koroner Kalp Hastalığı Tedavisinde Yoğun Yaşam Biçimi Değişiklikleri. In: Kabakçı G, editor. Harrison Kardiyolojide Gelişmeler. Ankara: Güneş Kitabevi; 2005.

8. Aydın D, Toplum ve Birey İçin Sağlıklı Yaşlanma: Yaşam Biçimi Rolü. SDÜ Tıp Fak Derg 2006;13(4):43-48.

9. Woldecherkos AS, Young-Xu Y, Blatt CM. Anxiety Worsens Prognosis in Patients With Coronary Artery Disease. Journal of The American College of Cardiology 2007;49(20):2022-2027.

10. Mott AM. Psychologic preparation to decrease anxiety associated with cardiac catheterization. J Vasc Nurs 1999;17(2):4149. [CrossRef]

11. Demir Ö, Aslantaş H. Koroner Anjiyografi ve Perkütan Transluminal Koroner Anjiyoplasti İşlemi Öncesi Uygulanan Müzik Eşliğinde Progresif Kas Gevşeme Egzersizinin Bireylerin Anksiyete Düzeylerine Olan Etkisi. Psikiyatri Hemşireliği Dergisi 2014;5(3):113-121. [CrossRef]

12. Dural G, Sarıtaş S. Akut Koroner Sendromlu Hastalarda Yaşam Kalitesi ve Yaşam Kalitesini Etkileyen Faktörler. Journal of Cardiovascular Nursing 2017;8(17):131-141. [CrossRef]

13. Koçyiğit H, Aydemir Ö, Fişek G, Ölmez N, Memiş A. Kısa Form 36 (KF-36) Türkçe Versiyonunun Güvenirliği Ve Geçerliliği Romatizmal Hastalığı Olan Bir Grup Hasta Ile Çalışma. Illaç ve Tedavi Dergisi 1999;12(2):102-106.

14. Spielberger CD, Gorsuch RL, Lushene E. Manual For The State-Trait Anxiety Inventory ('Self- Evaluation Questionaire'). Consulting Psychologist Pres; 1970.

15. Öner N, Le Compte A. Durumluluk-Sürekli Kaygı Envanteri El Kitabı. İstanbul: Boğaziçi Üniversitesi Yayınları; 1985.

16. Harkness K, Morrow L, Smith K, Kiczula M, Arthur HM. The Effect of Early Education on Patient Anxiety While Waiting For Elective Cardiac Catheterization. European Journal of Cardiovasculer Nursing 2003:2(2):113-121. [CrossRef]

17. Arthur HM, Smith KM, Natarajan MK. Quality of life at referral predicts outcome of elective coronary artery angiogram. Int J Cardiol 2008;126(1):32-36. [CrossRef]

18. De Jong-Watt WJ, Arthur HM. Anxiety and health-related qua- 
lity of life in patients awaiting elective coronary angiography. Heart Lung 2004;33(4):237-248. [CrossRef]

19. Balcı A, Enç N. The Effect of Audio-Visual Education Given to Coronary Angiography Patients over Physiological and Psychosocial Parameters. Turk J Card Nur 2013;4(5):41-50.

20. Unsar S, Sut N, Durna Z. Health- Related Quality of Life in Patients with Coronary Artery Disease. Turk J Card Nur 2007;22(6):501-507. [CrossRef]

21. Dilek F, Ünsar $S$, Süt N. Koroner Arter Hastalarında Yaşam Kalitesinin Değerlendirilmesi. Fırat Sağlık Hizmetleri Dergisi 2010;5:29-44.

22. Göçgeldi E, Babayiğit AM, Hassoy H, Açıkel CH, Taşçı İ, Ceylan S. Hipertansiyon Tanısı Almış Hastaların Algıladıkları Yaşam Kalitesi Düzeyinin ve Etki Eden Faktörlerin Değerlendirilmesi. Gülhane Tıp Dergisi 2008;50(3):172-179.

23. Aydın S, Yavuz T, Düver H, Kutsal A. 65 Yaş Üstü Hastalarda Ko- roner Bypass Operasyonlarının Yaşam Kaliteleri Üzerine Erken Dönem Etkisinin SF- 36 Testi ile Tespiti. Turkish Journal of Geriatrics 2002;5(2):64-67.

24. Bahar A, Tutkun H, Sertbaş G. Huzurevinde Yaşayan Yaşılıarın Anksiyete ve Depresyon Düzeylerinin Belirlenmesi. Anadolu Psikiyatri Dergisi 2005;6(4):227-239.

25. Astin F, Jones K, Trompson DR. Prevalence and Pattarns of Anxity and Depression in Patients Undergoing Elective Percutaneous Transluminal Coronary Angioplasty. Heart Lung 2005;34(6):393- 401. [CrossRef]

26. Özol D, Koçak MO, Çoşkunol I, Egemen A. Tüberkülozlu Hastalarda Kaygı Durumu Değerlendirilmesi. Solunum Hastalıkları 2005;16:66-70.

27. Demir M, Unsar S. Assessment of quality of life and activities of daily living in Turkish patients with heart failure. Int J Nurs Pract 2011;17(6):607-614. [CrossRef] 